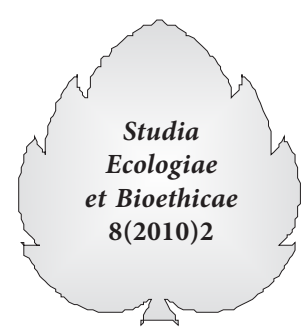

\title{
Zmienność runa leśnego w grądzie wysokim rezerwatu Las Bielański pod wpływem ruchu turystycznego
}

\begin{abstract}
Wstęp
Las Bielański to dobrze zachowany skrawek puszczy mazowieckiej, o znaczeniu nie tylko przyrodniczym, ale i kulturowym. Znajduje się on w dzisiejszych granicach Warszawy, co sprawia, że szczególnie narażony jest na uleganie antropopresji.

Status rezerwatu sprawia, że obecność człowieka w Lesie Bielańskim ograniczona jest tylko do ścieżek turystycznych i na nich się koncentruje. Wydawać by się mogło, że znacznie redukuje to ingerencję człowieka w ekosystem lasu, ogranicza ją do minimum. Z drugiej strony sieć ścieżek to jednak obcy element w układzie ekologicznym, którego naturalność ma być przecież chroniona. Zastanawiające jest, jak szlaki turystyczne wpływają na funkcjonowanie ekosystemu Lasu Bielańskiego, jakie powodują w nim zmiany. Jak daleko sięga wpływ ścieżki i na czym dokładnie polega? Do tej pory nie prowadzono badań dotyczących tego problemu na terenie Lasu Bielańskiego. Natomiast badania przeprowadzone na innych obszarach chronionych wykazują negatywne oddziaływanie szlaków turystycznych na funkcjonowanie ekosystemów leśnych i łąkowych (Holeksa J. I Holeksa K. 1981, PręDKi 1998, SokoŁowski 1981). Szkody wywołane na ścieżkach i w ich pobliżu to zniszczona roślinność, degradacja gleby, zaśmiecenie, hałas, zmiany w krajobrazie oraz strukturze i funkcjonowaniu ekosystemów (SoKоŁOWSKI 1981).

Niniejszy artykuł prezentuje wyniki badań przeprowadzonych we fragmencie grądu wysokiego Lasu Bielańskiego, których celem było właśnie zbadanie wpływu ruchu turystycznego na runo leśne.
\end{abstract}

\section{Teren i metoda badań}

W celu zbadania zmienności runa leśnego wybrano fragment lasu, opisany przez Sudnik-Wójcikowską (1982) jako grąd wysoki - odmiana sucha. Ta sama au- 
torka wraz z Solińską-Górnicką (1998) podaje dla tego zbiorowiska łacińską nazwę Tilio-Carpinetum calamagrostietosum. Zwarcie drzewostanu na wybranym terenie było jednorodne, co oznacza, że zarówno przy ścieżce, jak i w głębi lasu do runa docierała zbliżona ilość promieni słonecznych. Taki dobór terenu miał wyeliminować różnice w oświetleniu jako ewentualny czynnik powodujący zmienność.

Wzdłuż ścieżki o długości 125 m wytyczone zostały 3 linie: linia A w odległości 15-30 cm od krawędzi ścieżki, linia B - 5 m dalej i linia C - ok.10 m w głąb lasu (Ryc.1). Na każdej z tych linii co $5 \mathrm{~m}$ znajdował się kwadrat próbny o powierzchni $0,1 \mathrm{~m}^{2}$. Taki rozmiar powierzchni próbki, stosowany również przez Traczyk (1971), pozwala na dokładne zliczenie pędów poszczególnych gatunków.

Na każdej z 3 linii rozmieszczono 25 kwadratów, co w sumie dawało 75 próbek. Dla każdej próbki opisywano m.in. pokrycie powierzchni badawczej przez rośliny wyrażone $\mathrm{w} \%$, liczbę pędów gatunków i ich kondycję.

Pod uwagę wzięto tylko rośliny naczyniowe. Opis dotyczył gatunków runa leśnego, a nie wyższych pięter roślinności. Ilekroć więc pojawiają się w artykule nazwy drzew i krzewów odnoszą się one do osobników we wczesnej fazie rozwojowej, które swoją wysokością nie wykraczają poza warstwę runa.

Badania wykonywane były trzy razy w roku 2007, w odstępach 3-miesięcznych: w pierwszej dekadzie kwietnia, lipca i października. Umożliwiło to rejestrację zmian sezonowych.

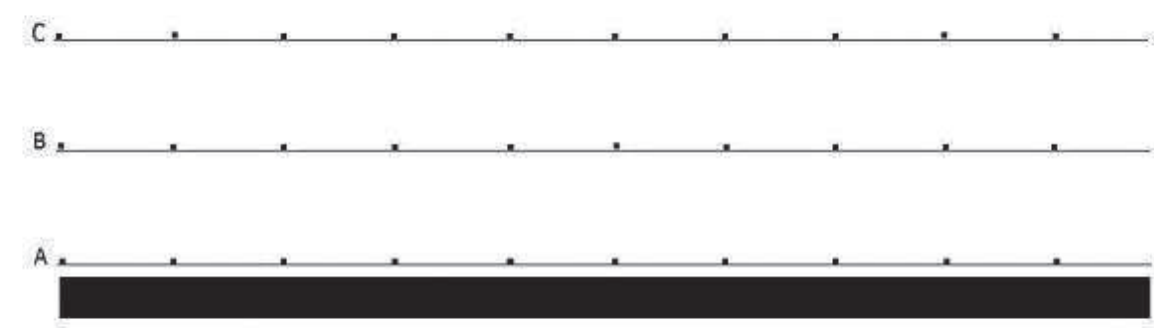

Ryc. 1. Schemat rozmieszczenia próbek na liniach $A, B$ i $C$ (na czarno zaznaczona jest powierzchnia ścieżki turystycznej, punkty rozmieszczone na liniach $A, B$ i C to próbki $w$ kształcie kwadratu o powierzchni $0,1 \mathrm{~m}^{2}$ )

Fig. 1. The scheme of sample distribution along $A, B$ and $C$ lines. The tourist path area is marked in black, the points shown along the lines denote sample squares of $0.1 \mathrm{~m} 2$ in area

\section{Wyniki}

1. Rozkład liczby pędów

Dla wykazania rozmieszczenia pędów poszczególnych gatunków sprawdzono zgodność ich liczby z rozkładem Poissona. Obliczeń zgodności z rozkładem 
Poissona dokonano dla takich gatunków, które wystąpiły co najmniej w 5 próbkach w linii w danym sezonie.

Stosunek wariancji do średniej liczby pędów u gatunków: Anemone nemorosa, Galeobdolon luteum, Quercus sp., Maianthemum bifolium, był w każdym przypadku większy od jedności, co oznacza, że mają one skupiskowy rozkład (Tab. 1). Carpinus betulus w trzech seriach (wiosna, linia A i B, lato - B) wykazal skupiskowość, a w jednej równomierność (wiosna $\mathrm{C}$ ). Acer platanoides natomiast w dwóch liniach ma rozkład skupiskowy (wiosna $B$, jesień $A$ ), a w czterech równomierny (Lato - B, C, Wiosna - B, C). Tak więc w znacznej części rozkłady liczby pędów w próbkach odbiegały od rozkładu Poissona (rozkładu losowego) i w większości przypadków były skupiskowe. Jedynym wyjątkiem był Acer platanoides.

Tab. 1. Stosunek wariancji do średniej liczby pędów (WM) poszczególnych gatunków $w$ kolejnych sezonach (WM<1 oznacza rozkład równomierny, WM=0 rozkład losowy, $W M>1$ rozkład skupiskowy)

Table 1. The seasonal changes of variance to mean (WM) relation calculated for separate species in consecutive seasons. $W M<1$ denotes even distribution, WM=1 stands for random one, and $W M>1$ stands for clumped distribution

\begin{tabular}{|c|c|c|c|}
\hline \multicolumn{4}{|c|}{ Wiosna - Spring } \\
\hline \multirow{2}{*}{$\begin{array}{l}\text { Gatunku } \\
\text { Species }\end{array}$} & \multicolumn{3}{|c|}{$\begin{array}{c}\text { Stosunek wariancji do średniej (WM) } \\
\text { Relation of variance to mean (WM) }\end{array}$} \\
\hline & Linia A - Line A & Linia $\mathrm{B}$ - Line $\mathrm{B}$ & Linia $C$ - Line $C$ \\
\hline Acer platanoides & - & 1,12 & - \\
\hline Anemone nemorosa & 17,91 & 14,17 & 31,25 \\
\hline Carpinus betulus & 5,52 & 2,51 & 0,95 \\
\hline Galeobdolon luteum & - & 5,73 & 8,53 \\
\hline \multicolumn{4}{|l|}{ Lato - Summer } \\
\hline Acer platanoides & - & 0,79 & 0,82 \\
\hline Anemone nemorosa & 1,75 & - & 1,22 \\
\hline Carpinus betulus & - & 3,05 & - \\
\hline Galeobdolon luteum & - & 2,71 & 5,85 \\
\hline Maianthemum bifolium & - & - & 6,98 \\
\hline Quercus sp. & - & 2,22 & 2,53 \\
\hline \multicolumn{4}{|l|}{ Jesień - Autumn } \\
\hline Acer platanoides & 1,75 & 0,82 & 0,85 \\
\hline Galeobdolon luteum & - & 3,64 & 5,65 \\
\hline Quercus sp. & - & 3,00 & 1,75 \\
\hline
\end{tabular}


Rozkład liczby pędów danego gatunku w większości przypadków nie zmieniał się wraz ze zmianą linii, na której był badany. Jedynym odstępstwem jest tu Carpinus betulus, który podczas badań wiosennych na linii A i B miał rozkład skupiskowy, natomiast na $\mathrm{C}$ równomierny; oraz Acer platanoides, który podczas badań jesiennych miał na linii A rozkład skupiskowy, a na $\mathrm{B}$ i $\mathrm{C}$ równomierny.

\section{Frekwencja gatunków}

Frekwencja to miara szansy znalezienia danego gatunku w dowolnym kwadracie próbnym (KeRSHAW 1978). Nie można traktować jej jako dokładnej miary liczebności gatunku, choć w pewien sposób koresponduje ona z tą wartością.

Wiosną najwyższą frekwencją wykazały się Anemone nemorosa, Carpinus betulus i Galeobdolon luteum. Podczas badan letnich i jesiennych były to Galeobdolon luteum i Acer platanoides. Hedera helix, Geranium robertianum, Quercus sp., Convallaria majalis, Ficaria verna, Cratageus sp. i Alliaria petiolata w żadnym z sezonów nie pojawiły się na linii A, położonej najbliżej ścieżki.

Frekwencja poszczególnych gatunków zmieniała się nie tylko w zależności od odległości od ścieżki, ale także w zależności od sezonu, w którym wykonane były badania (Ryc. 2).

3. Liczba pędów na liniach A, B i C

Liczba pędów poszczególnych gatunków zmieniała się ze względu na odległość od ścieżki. Zbadano, czy te różnice pomiędzy liniami A, B i C są istotne. Najpierw sprawdzono, czy pomiędzy liniami jest choć jedna istotna różnica stosując analizę wariancji Kruskal-Wallisa. Jeśli tak było stosowano następnie test MannaWithneya, aby wykazać, między którymi liniami ta różnica jest istotna. Pod uwagę wzięto tylko te gatunki, które wystąpiły co najmniej w 5 próbkach na jednej z linii.

Różnice w liczbie pędów wykryto dla gatunków: Galeobdolon luteum, Anemone nemorosa, Quercus sp. Zawsze różnice te występowały między linią A, położoną najbliżej ścieżki i linią B. Linia B i C nie różnią się istotnie pod względem liczby pędów. 


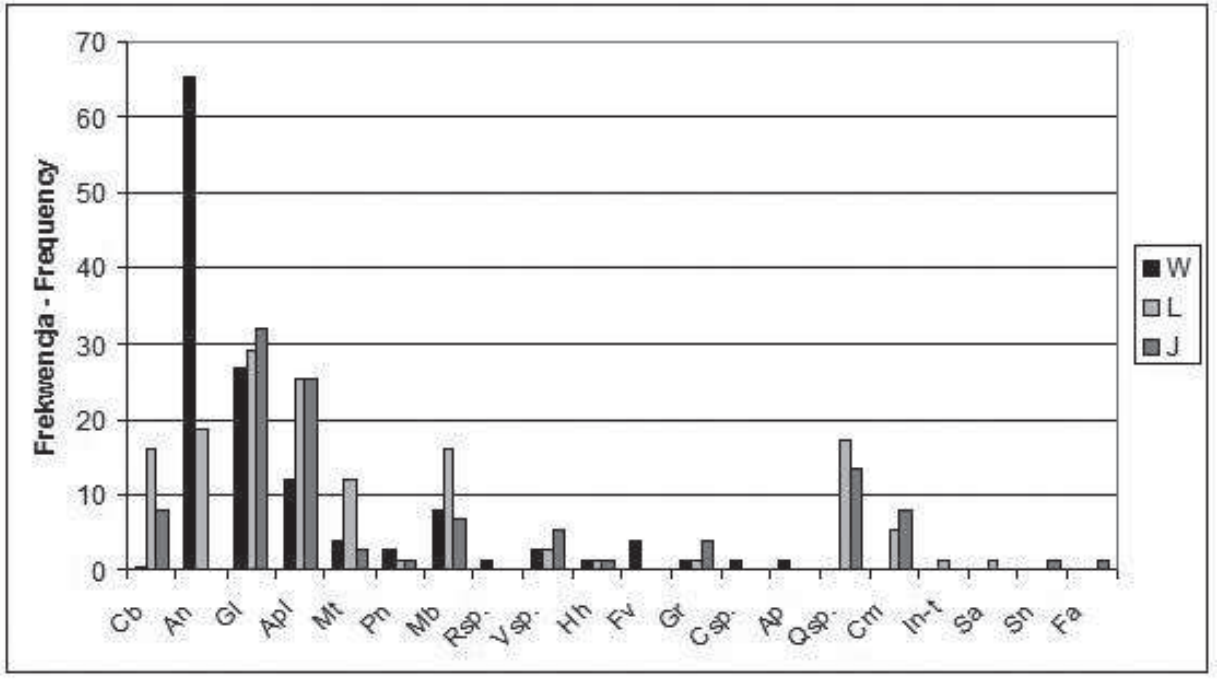

Ryc. 2. Frekwencja gatunków wyrażona w [\%]. 1 - wiosna, 2 - lato, 3 - jesień; Cp Carpinus betulus, An - Anemone nemorosa, Gl-Galeobdolon luteum, Apl-Acer platanoides, Mt - Moehringia trinervia, Pn - Poa nemorosa, Mb - Maianthemum bifolium, Rsp. - Ribes sp., Vsp. - Viola sp., Hh - Hedera helix, Fv - Ficaria verna, Gr Geranium robertianum, Csp. - Cratageus sp., Ap - Alliaria petiolata, Qsp. - Quercus sp.,

$\mathrm{Cm}$ - Convallaria majalis, In-t - Impatiens noli-tangere, Sa - Sorbus aucuparia, Sn -

Sambucus nigra, Fa - Frangula alnus

Fig. 2. Frequency of the species in [\%]. 1 - spring, 2 - summer, 3 - autumn; Cp Carpinus betulus, An - Anemone nemorosa, Gl-Galeobdolon luteum, Apl-Acer platanoides, Mt - Moehringia trinervia, Pn - Poa nemorosa, Mb - Maianthemum bifolium, Rsp. - Ribes sp., Vsp. - Viola sp., Hh - Hedera helix, Fv - Ficaria verna, Gr Geranium robertianum, Csp. - Cratageus sp., Ap - Alliaria petiolata, Qsp. - Quercus sp., $\mathrm{Cm}$ - Convallaria majalis, In-t - Impatiens noli-tangere, Sa - Sorbus aucuparia, Sn Sambucus nigra, Fa - Frangula alnus

4. Stopień pokrycia kwadratów próbnych

Procent pokrycia powierzchni próbek przez nadziemne części roślin uznawany jest za dobrą miarę liczebności gatunków, zwłaszcza w przypadku, gdy trudne lub niemożliwe jest zliczenie liczby osobników (KershaW 1978). Badania nad zmiennością runa wykazały, że stopień pokrycia zmienia się wraz z odległością od ścieżki. Testy statystyczne (analiza wariancji Kruskal-Wallisa oraz test Manna-Withneya) dowiodły, że średnie pokrycie procentowe na linii A jest istotnie niższe od linii położonych dalej od szlaku turystycznego (Ryc. 3). 


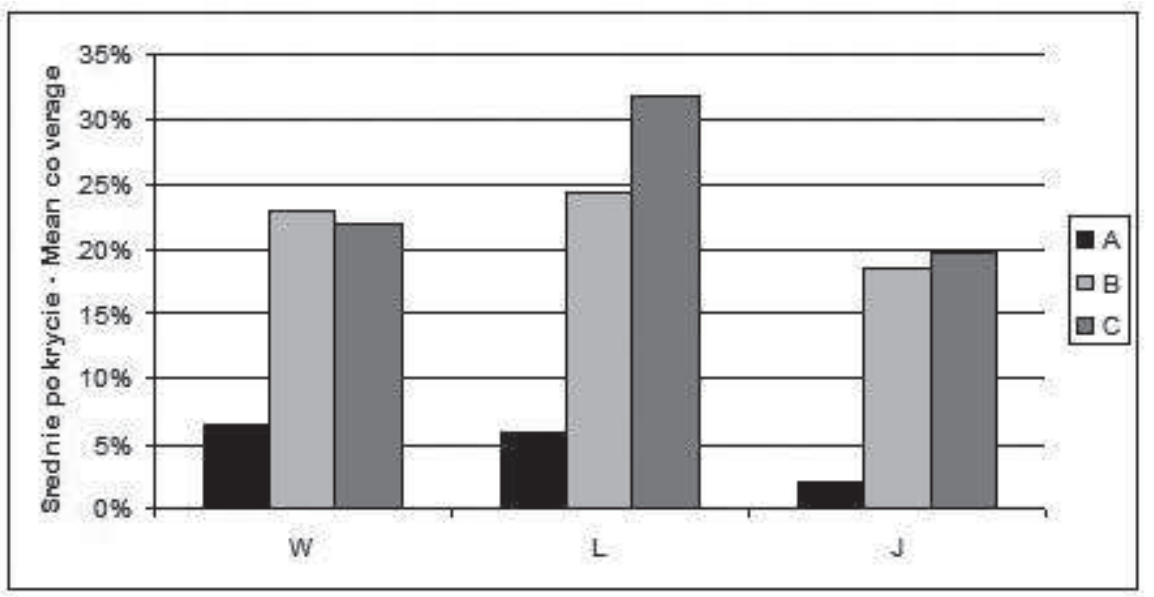

Ryc. 3. Średnie pokrycie powierzchni próbnych na linii A, B i C. W-wiosna, $L$ - lato, J-jesień Fig. 3. Mean coverage per sample along $A, B$ and $C$. $W$-spring, $L-$ summer, J-autumn

5. Grab pospolity (Carpinus betulus) w runie grądu wysokiego

Grab (Carpinus betulus) jest uznawany za główny gatunek grądotwórczy (Faliński, Pawlaczyk 1993). Dlatego też ze względu na znaczenie tego gatunku dla funkcjonowania całości zbiorowiska warto dokładniej prześledzić wpływ ścieżki turystycznej na ten konkretny gatunek.

Rozkład liczby pędów tego gatunku był w większości badanych linii skupiskowy. Liczba pędów grabu nieznacznie różniła się na poszczególnych liniach (Ryc. 4). Zmienność między liniami była jednak na tyle mała, że test statystycz-

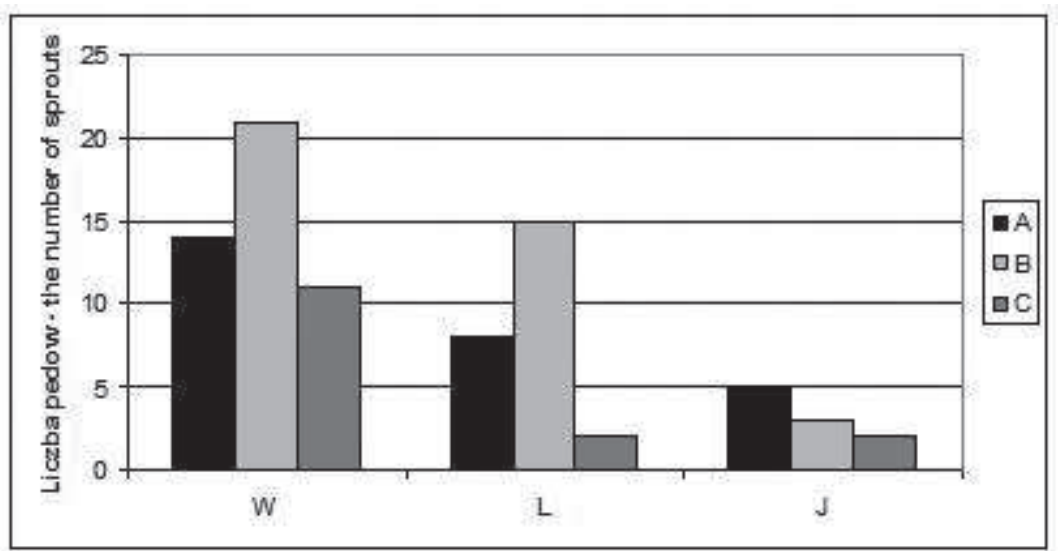

Ryc. 4. Liczba pędów grabu na liniach A, B i C. W-wiosna, L-lato, J-jesień Fig. 4. The number of hornbeam sprouts along $A, B$ and $C$ lines. $W-$ spring, $L$-summer,

$$
J \text { - autumn }
$$


ny - analiza wariancji Kruskal-Wallisa nie wykazał istotnych różnic. Natomiast różnica w liczbie pędów w poszczególnych sezonach jest znaczna. Wiosną zanotowano 46 pędów, latem 25, jesienią tylko 10 .

Frekwencja odwzorowuje liczbę pędów, a co za tym idzie, są tu nieduże różnice lub brak jest różnic pomiędzy liniami, a znaczne są różnice pomiędzy wartościami w kolejnych sezonach (Ryc. 5).

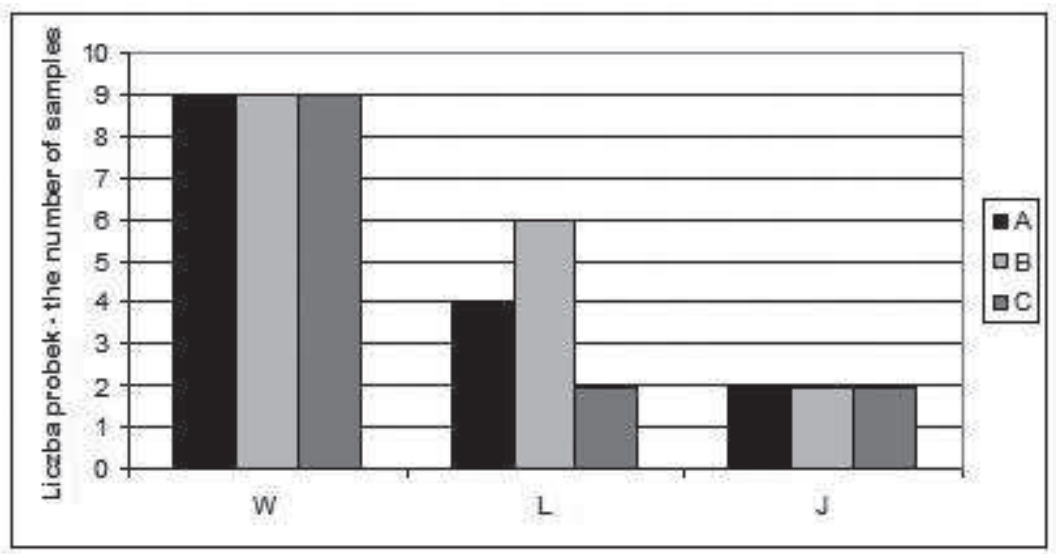

Ryc. 5. Liczba próbek, w których wystąpił grab na liniach A, B i C. W-wiosna, $L$ - lato, J-jesień

Fig. 5. The number of samples containing hornbeam sprouts along $A, B$ and $C$ lines.

$W$ - spring, $L$ - summer, $J$ - autumn

6. Ślady obecności zwierząt

Podczas badań odnaleziono ślady bytowania ssaków leśnych. Na liniach B i C w kwadratach próbnych lub w ich bliskim sąsiedztwie występowały norki gryzoni. O obecności gryzoni świadczą również pozgryzane pędy i kwiaty zawilca gajowego (Anemone nemorosa), rzadziej gajowca żółtego (Galeobdolon luteum), które odnotowano na linii $\mathrm{C}$, oraz w jednym przypadku na linii $\mathrm{B}$.

W odległości nieco ponad $10 \mathrm{~m}$ od ścieżki odnaleziono miejsce, które prawdopodobnie jest legowiskiem saren. W pobliżu był również wyraźnie zgryziony przez zwierzę młody klon zwyczajny (Acer platanoides) oraz odchody sarny.

7. Choroby i uszkodzenia mechaniczne roślin

Odnotowano uszkodzenia mechaniczne roślin wywołane zgryzaniem przez zwierzęta, co opisane jest powyżej. Poza tym w badaniach letnich można spotkać zdeptane rośliny na linii A. Pośrodku tej linii jest miejsce, gdzie kilka konwalijek dwulistnych (Maianthemum bifolium) jest wyraźne przydeptane, a obok nich jest złamany jarząb pospolity (Sorbus aucuparia). Siewki i osobniki juwenilne dębu 
(Quercus sp.) zaatakowane są przez owada tyszerkę płaskowiaczek- (Tischeria ekebladella Huebner, BJK.), co objawia się białymi plamami i uszkodzeniami liści.

\section{Dyskusja}

1. Analiza rozkładu liczby pędów

Większość gatunków dla których możliwe było sprawdzenie rozkładu liczby pędów podczas badań nad zmiennością runa wykazała skupiskowość.

Rozkład liczby pędów zależy w dużym stopniu od morfologii osobnika i sposobu rozmnażania się (KeRsHAW 1978). Ważne jest zwłaszcza to, czy dany gatunek wytwarza rozłogi. Może dojść wtedy to wytworzenia płatów składających się z pędów danej rośliny. Jest tak w przypadku Galeobdolon luteum (TraczyK 1959). Maianthemum bifolium również tworzy podziemne, wijące się kłącze, co jest cechą morfologiczną sprzyjającą tworzeniu się skupisk. Podobnie jest z Anemone nemorosa (Mowszowicz 1987).

Rośliny o nasionach ciężkich lub owocach, w których znajduje się kilka nasion na ogół wykazują rozmieszczenie skupiskowe (Kershaw 1978). To zjawisko tłumaczy skupiskowość dębu (Quercus sp.). Wręcz przeciwnie jest z klonem (Acer platanoides). Jego nasiona zaopatrzone $\mathrm{w}$ aparat lotny przenoszone są przez wiatr na duże odległości i rozmieszczają się dość równomiernie.

Typ rozkładu danego gatunku nie zmienia się w zależności od badanej linii. Można więc mniemać, że wpływ bliskości ścieżki turystycznej nie jest na tyle silny, aby znacząco zaburzyć biologię gatunku, czy sposób rozmnażania się, od którego rozkład jest uzależniony. Jedynym odstępstwem jest tu Carpinus betulus, który podczas badań wiosennych na linii A i B miał rozkład skupiskowy, natomiast na $C$ równomierny (poruszone dalej); oraz Acer platanoides, który podczas badań jesiennych miał na linii A rozkład skupiskowy, a na B i C równomierny. Rozmieszczenie młodych pędów klonu w dnie lasu powinno być zbliżone do losowego lub równomierne. Jesienią jednak na linii A zanotowano skupiskowy rozkład liczby pędów. W bezpośrednim sąsiedztwie ścieżki musiał istnieć czynnik powodujący, iż nasiona wykiełkowały tylko w niektórych punktach lub że część siewek lub osobników juwenilnych obumarła. Nie odkryto co dokładnie było przyczyną zmiany rozkładu liczby pędów w tym przypadku.

\section{Różnice w wartościach frekwencji}

Wiosną gatunki o najwyższej frekwencji to Anemone nemorosa, Carpinus betulus i Galeobdolon luteum. Są to gatunki, które o tej porze roku budują runo. Warto więc zastanowić się nad ich pochodzeniem - czy są one typowe dla grądu czy raczej obce. W tym celu sprawdzono czy któryś z najczęściej spotkanych gatunków jest gatunkiem charakterystycznym, a jeżeli tak to dla jakiego syntaksonu. Gatunek charakterystyczny występuje wyłącznie lub prawie wyłącznie w fi- 
tocenozach danego syntaksonu, z wyraźnie większą liczebnością lub pokryciem niż gdzie indziej (Matuszkiewicz 2005). Okazuje się, że gatunki o najwyższej frekwencji to gatunki bezpośrednio charakterystyczne dla grądów lub typowe dla rzędów lub klasy zespołów leśnych, do których grądy należą. Jeżeli chodzi o Anemone nemorosa to Matuszkiewicz (2005) zalicza go do gatunków charakterystycznych dla całej klasy Querco-Fagetea, Galeobdolon luteum jest gatunkiem charakterystycznym dla rzędu Fagetalia sylvaticae, a Carpinus betulus dla związku Carpinion betuli (Matuszkiewicz 2005). Podczas badań letnich i jesiennych największą frekwencją odznaczyły się Galeobdolon luteum i Acer platanoides. Acer platanoides jest gatunkiem charakterystycznym dla klasy Querco-Fagetea. Uwagę zwraca zmienność sezonowa frekwencji. Latem i jesienią te same gatunki osiągnęły najwyższą frekwencję. Przez wszystkie 3 sezony wysoką frekwencją charakteryzuje się Galeobdolon luteum. Wiosną najwyższą frekwencję osiąga Anemone nemorosa. Jest to wczesnowiosenny geofit, co tłumaczy tak częste występowanie wiosną, a zamieranie w późniejszych sezonach. Wysoka frekwencja Carpinus betulus podczas badań wiosennych, a niska w późniejszych sezonach została wyjaśniona dalej.

Z ekologicznego punktu widzenia istotne są nie tylko gatunki, których frekwencja jest najwyższa, ale również gatunki rzadko występujące w próbach, pojawiające się sporadycznie. Kryterium dla wyróżnienia tych gatunków było pojawienie się tylko w jednej próbce $\mathrm{w}$ danym sezonie. Taką frekwencję wiosną osiągnęły: Ribes alpinum, Hedera helix, Geranium robertianum, Alliaria petiolata, Cratageus sp. Latem były to ponownie Hedera helix i Geranium robertianum oraz Impatiens noli-tangere, Poa nemorosa, Sorbus aucuparia. Jesienią w tylko w jednej próbce pojawiły się Hedera helix, Poa nemorosa, Frangula alnus, Sambucus nigra. Niektóre z tych gatunków są związane z grądami: Ribes alpinum i Poa nemorosa to gatunki charakterystyczne dla klasy Querco-Fagetea, Impatiens noli-tangere dla rzędu Fagetalia. Są tu też dwa gatunki powiązane z klasą Artemisietea vulgaris, a konkretniej z podklasą Galio-urticenea (naturalne i półnaturalne nitrofilne zbiorowiska typu okrajkowego na żyznych siedliskach świeżych, wilgotnych lub mokrych, w różnym stopniu zacienionych). Gatunek charakterystyczny dla rzędu Glechometalia znajdującego się w tej podklasie to Alliaria petiolata, zaś gatunek charakterystyczny dla związku zespołów Alliarion należącego do tego rzędu to Geranium robertianum (MATUszKIEwICZ 2005). Oba te gatunki preferują glebę zasobną $\mathrm{w}$ azot. $\mathrm{W}$ badaniach zanotowano występowanie też trzeciego gatunku powiązanego fitosocjologicznie z ze związkiem Alliarion, a charakterystycznego dla zespołu Epilobio-Geranietum robertiani. Jest to Moehringia trinervia, należący do rodziny goździkowatych.

Frekwencja poszczególnych gatunków osiągała zróżnicowane wartości w zależności od położenia względem ścieżki turystycznej. Hedera helix, Geranium robertianum, Quercus sp., Convallaria majalis, Ficaria verna, Cratageus sp. i Alliaria pe- 
tiolata w żadnym z sezonów nie pojawiły się na linii A, położonej najbliżej ścieżki. Większość z tych gatunków została również zakwalifikowana do grupy rzadkich, czyli pojawiających się tylko w jednej próbce w danym sezonie. Ficaria verna występuje tylko wiosną $\mathrm{w} 3$ próbkach. Jest to gatunek z rodziny jaskrowatych preferujących wilgotne siedliska, charakterystyczny m.in. dla rzędu Fagetalia sylvaticae i związku Alno-Ulmion. Nieco częściej występuje Convallaria majalis.

Gatunki nie pojawiające się na linii A różnią się od siebie. Trudno więc odnaleźć jedną wspólną przyczynę braku tych roślin w pobliżu ścieżki. Są to rośliny pojawiające się niezwykle rzadko w runie badanego grądu, stąd też fakt, iż nie pojawiają się na linii A nie musi świadczyć o negatywnym wpływie ścieżki turystycznej. Może to być przypadek.

Podobnie jest z gatunkami występującymi tylko na linii A. Jest to Ribes alpinum, Impatiens noli-tangere, Sorbus aucuparia. Są to jednocześnie gatunki o niskiej frekwencji. Przewidywanym wynikiem było występowanie na linii A zwiększonej liczby gatunków obcych dla grądów. Po wykonaniu badań okazało się, że zjawisko takie nie występuje. Skład gatunkowy runa jest typowy dla grądów, nawet przy ścieżce, gdzie zwiększona jest możliwość wtargnięcia obcych przybyszów.

Na podstawie obecności lub braku gatunków rzadko występujących nie można wnioskować na temat wpływu ścieżki, ale gatunki o dużej frekwencji, które są częste i dobrze rozwijają się w danym zbiorowisku mogą tych informacji dostarczyć. Wśród takich właśnie gatunków zauważono zmienność w zależności od linii. Najbliżej ścieżki frekwencja każdego z gatunków pojawiających się często była niższa niż na liniach w głębi lasu. Jest tu widoczny wpływ ścieżki.

3. Zahamowanie rozwoju życia przyrodniczego w bezpośrednim sąsiedztwie ścieżki turystycznej

Mimo, iż obecność ścieżki na badanym terenie nie wpływa na rozkład liczby pędów gatunku, czy na zwiększenie w jej sąsiedztwie frekwencji gatunków obcych, to wpływ ten jednak jest widoczny w innych badanych elementach. Na linii A, czyli w bliskim sąsiedztwie ścieżki istotnie niższe jest pokrycie procentowe powierzchni badawczych, mniejsza jest liczba pędów i frekwencja gatunków występujących często, o czym wspomniano już wcześniej. Można tu wręcz mówić o zahamowaniu rozwoju życia przyrodniczego w sąsiedztwie szlaku.

Wydawać by się mogło, że takie wyniki uwidaczniają bezpośredni wpływ turystów na runo leśne. Nasuwa się bowiem podejrzenie, że to oni depczą rośliny znajdujące się tuż przy ścieżce, uniemożliwiając tym samym ich prawidłowy rozwój, niszcząc je. Badania jednak wykazują, że uszkodzenia mechaniczne roślin spowodowane przez człowieka występują bardzo rzadko. Jest tylko jedno miejsce na linii A gdzie wyraźnie widać „zdeptanie roślin” podczas badań letnich, a powierzchnia objęta uszkodzeniami jest nieduża. Musi istnieć więc inny czynnik powodujący 
zmniejszoną liczbę pędów i niższe pokrycie na linii A. Może nim być degradacja gleby na samych szlakach oraz w bliskim ich sąsiedztwie. Nie ma tam bowiem ściółki, nie może tworzyć się próchnica, zdarta jest wierzchnia warstwa gleby, a co za tym idzie łatwiej wymywane są składniki mineralne. Poza tym zmieniona jest struktura gleby - jest ona zbita i twarda. Do problematyki tej nawiązuje między innymi Prędki (1998). Trudno jednak stwierdzić jak daleko sięgają te zmiany w glebie i w jakim stopniu przyczyniają się do wyjaśnianego zjawiska.

Zahamowanie rozwoju życia przyrodniczego przy ścieżce objawia się nie tylko w świecie roślin, ale także u zwierząt. Rośliny występują w mniejszej liczbie na linii $\mathrm{A}$, natomiast na dwóch pozostałych liniach nie ma już istotnych różnic w liczbie pędów czy pokryciu procentowym powierzchni próbnych. Można więc stwierdzić, że wpływ na roślinność runa sięga nie dalej niż do $5 \mathrm{~m}$ od krawędzi szlaku. Zwierzęta odczuwają natomiast znacznie silniej wpływ ścieżki turystycznej. Ślady obecności saren są tylko na linii C, $10 \mathrm{~m}$ od krawędzi ścieżki. Miejsce żerowania gryzoni znajdowano również głównie na linii C. Norki gryzoni ulokowane były zarówno na linii C, jak i B. Nigdy jednak nie natrafiono na ślad bytowania zwierząt w odległości mniejszej niż $5 \mathrm{~m}$ od krawędzi szlaku turystycznego. Wpływ na to może mieć hałas na ścieżkach, drżenie ziemi spowodowane ruchem, obecność obcych zapachów, pochodzących od ludzi. Psy, nawet gdy prowadzone są na smyczy, nie trzymają się ściśle granic ścieżki, co również może odstraszać zwierzęta z tych stref.

4. Rozwój grabu pospolitego w runie w pobliżu ścieżek turystycznych Grab (Carpinus betulus) jest jednym z gatunków tworzących drzewostan w grądach, a co za tym idzie dość licznie występuje również w runie. Analizując liczbę pędów i frekwencję grabu nie zauważono zmienności wywołanej obecnością szlaku turystycznego. Dla ogółu gatunków stwierdzono zahamowanie rozwoju w pobliżu ścieżki. Jeśli chodzi o grab zjawisko takie nie występuje. Okazuje się więc, że grab jest gatunkiem dość odpornym na oddziaływanie ruchu turystycznego.

Zazwyczaj siewki grabu rozmieszczone są na dnie lasu prawie losowo, natomiast osobniki immaturalne i wirginilne skupiskowo. To co wpływa $z$ czasem na zmianę wzoru rozmieszczenia to duża śmiertelność siewek. Przeżywają tylko osobniki, które wykiełkowały w miejscach o wystarczającym dostępie światła (Faliński, PaWlaczyk 1993).

Zgodność z podręcznikowym modelem rozkładu typowym dla grabu nastąpiła na linii C podczas badań wiosennych oraz na linii B latem. Siewki na linii $\mathrm{C}$ wiosną były bowiem rozmieszczone prawie losowo. Natomiast starsze osobniki podczas badań letnich wykazały skupiskowość, co oznacza, że przeżyły tylko siewki w punktach o najbardziej optymalnych warunkach w dnie lasu. Od tego modelu odbiegają typy rozkładów na linii A i B wyliczone z danych zebranych podczas badań wiosennych. Mimo tego, że są tam siewki nie mają one rozkładu 
zbliżonego do losowego. Wyjaśnienie tego zjawiska należałoby oprzeć na jednej $\mathrm{z}$ dwóch hipotez. Pierwsza $\mathrm{z}$ nich zakłada, że nasiona rozmieszczone są $\mathrm{w}$ dnie lasu równomierne, w sposób zbliżony do losowego, ale kiełkują tylko w niektórych miejscach, w których być może są lepsze warunki. Na etapie kiełkowania światło nie odgrywa jednak znaczącej roli, więc musi to być inny czynnik występujący w pewnych punktach. Druga hipoteza zakłada, że już nasiona zostały rozmieszczone skupiskowo. Czynnikiem, który może mieć na to wpływ jest obecność gryzoni. Pierwotnie nasiona rozniesione są przez wiatr równomiernie, ale gryzonie gromadzą je, a nie wszystkie zjadają. Zjawisko zmiany wzoru rozmieszczenia siewek grabu z równomiernego na skupiskowy na terenach gdzie występują gryzonie notowane było już wcześniej (FALiŃski, PaWLACZYK 1993). Nie znaleziono jednak śladów gryzoni na linii A, gdzie nastąpiła zmiana typu rozkładu liczby pędów. Stawia to w wątpliwość teorię według której gryzonie są sprawcami skupiskowego rozmieszczenia nasion na badanym terenie.

Zjawisko dużej śmiertelności siewek wyjaśnia również znaczną różnicę w liczbie pędów w poszczególnych sezonach. Wiosną zanotowano 46 pędów, latem 25 , a jesienią tylko 10. Najwięcej jest siewek i osobników juwenilnych, starsze osobniki spotyka się bardzo rzadko. Wcześniejsze badania nad strukturą populacyjną drzewostanu w rezerwacie Las Bielański wykazały, że w populacji grabu ponad 90\% stanowią siewki i osobniki juwenilne (SymONIDES, SolińsKa-GóRNICKA 1991).

\section{Podsumowanie}

Analiza badań przeprowadzonych w 2007 r. w grądzie wysokim rezerwatu Las Bielański dostarczyła odpowiedzi na pytania postawione we wstępie artykułu. W runie leśnym w pobliżu ścieżek zauważono pewne zmiany. Wnioski można zebrać w następujących punktach:

1. Rozkład liczby pędów większości gatunków jest skupiskowy i nie zmienia się wraz z odległością od szlaku turystycznego (jest uwarunkowany biologią gatunku).

2. W bliskim sąsiedztwie ścieżki (do $5 \mathrm{~m}$ ) następuje zahamowanie rozwoju pokrywy roślinnej wyrażające się $\mathrm{w}$ istotnie niższym pokryciu procentowym powierzchni próbnych i mniejszej liczbie pędów w próbce niż na liniach B i C, w głębi lasu.

3. Brak jest śladów obecności zwierząt w odległości poniżej $5 \mathrm{~m}$ od krawędzi ścieżki. Większość śladów zanotowano w odległości $10 \mathrm{~m}$ od szlaku turystycznego.

4. Gatunki o najwyższej frekwencji to gatunki typowe dla grądów lub dla syntaksonów, do których związek grądów należy.

5. Brak jest istotnych różnic w liczbie pędów i frekwencji grabu (Carpinus betulus) na poszczególnych odległościach od ścieżki turystycznej. Liczba pędów tego gatunku największa jest wiosną i stopniowo spada, co uwarunkowane jest dużą śmiertelnością siewek i osobników juwenilnych z powodu niedostatku światła. 


\section{Bibliografia}

Faliński J.B., Pawlaczyk P., 1993 - Zarys ekologii. [W:] Grab zwyczajny - Carpinus betulus L., PAN, Instytut Dendrologii w Kórniku, 157-263

Holeksa J., Holeksa K., 1981 - Oddziaływanie turystyki na roślinność Babiogórskiego Parku Narodowego, Parki nar. Rez. Przyr. 2,1: 3-24

Kershaw K. A., 1978 - Ilościowa i dynamiczna ekologia roślin, PWN, Warszawa

Matuszkiewicz W., 2005 - Przewodnik do oznaczania zbiorowisk roślinnych Polski, PWN, Warszawa

Mowszowicz J., 1987 - Flora wiosenna, Wydawnictwa Szkolne i Pedagogiczne, Warszawa

PRĘDKI R., 1998 - Ocena stopnia zniszczeń środowiska przyrodniczego wzdłuż szlaków turystycznych Bieszczadzkiego Parku Narodowego, Przeg. Przyr. 9, 1/2: 195-200

SокоєоwsKi A., 1981 - Turystyka w polskich parkach narodowych i jej wpływ na przyrodę parków, Parki nar. Rez. Przyr. 2,1: 25-31

SuDNIK-WójCikowsKa B., 1982 - Szata roślinna Lasu Bielańskiego. [W:] Las Bielański w Warszawie rezerwat przyrody, Baum T., Trojan P., (red.), PWN, Warszawa, 113-178

Symonides E., SolińsKA-GóRnickA B., 1991 - Struktura populacyjna drzewostanu w rezerwacie Las Bielański jako wskaźnik przekształceń biocenozy, Prądnik, Prace i materiały Muzeum im. prof. Władysława Szafera, 4: 27-37

Sudnik-Wójcikowska B., Solińska-GóRnicka B. 1998, - Rezerwat przyrody „Las Bielański” $w$ Warszawie : ścieżka przyrodnicza, Wydawnictwa Akcydensowe, Warszawa

TRACZYK H., 1971 - Relation between productivity and structure of the her layer in associations on „The Wild Apple-tree Island” (Masurian Lake District), Ekologia Polska, 19, 25: 333-363

TrACzyк T., 1959 - Rośliny lasu liściastego, PZWS, Warszawa

\section{Tourist traffic as a factor affecting ground cover in an oak-hornbeam association of the Las Bielański Reserve}

\section{SUMMARY}

Las Bielański covers 150 hectares in area is a unique remnant of the ancient Mazowiecka Forest. At present 130 hectares out of 150 hectares are a nature reserve, where the influence of humans is limited only to tourist paths.

The aim of this research was to estimate a possible impact of use the path by humans on the development of nearby plants. Namely, whether the presence of the path induces any changes, and if so, what sort and scope of the changes is seen.

A $125 \mathrm{~m}$ long section of a turist path, located in an oak-hornbeam association was chosen. Three sampling lines parallel to the path were traced: line A - 15-30 cm distant from the path's edge, line $\mathrm{B}-5 \mathrm{~m}$ away, and line $\mathrm{C}$ - about $10 \mathrm{~m}$ away from the path's edge (Fig. 1). Plants were collected using sample squares of $0.1 \mathrm{~m}^{2}$ in area, distributed evenly along each line (25 samples per line, i.e., 75 samples altogether).

The data collected in the field were analysed statistically. Most of the species exhibit clumped distribution of the amount of sprouts (Tab. 1). This phenomenon is seen in 
each line. In order to demonstrate the differences in abundance of sprouts, as well as differences in plant cover between the samples taken along the three lines, nonparametric statistics were applied - the Mann-Whitney test and Kruskal-Wallis ANOVA. The results of those analyses show for restricted plant cover in the line closest to the path: the percentage of the coverage and the number of sprouts per sample in line A are lower than those estimated for lines B and C (Fig. 3). The species occurring most frequently are those typical of the oak-hornbeam association. The estimate of frequency is the lowest for all the species directly in the closest vicinity of the path (Fig. 2). Seasonal variability is evident, too.

No presence of animals was noticed within the distance of $5 \mathrm{~m}$ from the path's edge. The majority of animal traces occurred around line $\mathrm{C}$, about $10 \mathrm{~m}$ distance from the path.

Particular attention was paid to distribution of hornbeams (Carpinus betulus) - the predominant species in the oak-hornbeam association. No significant differences were found between the three lines as far the amount of hornbeam sprouts and frequency is concerned (Fig. 4 and 5). The number of sprouts of this species is the highest in spring, and it decreases gradually, due to heavy mortality of seedlings and juvenile specimens, with progressive light shortage. It means, the tourist traffic is not the only factor affecting plant abundance. 